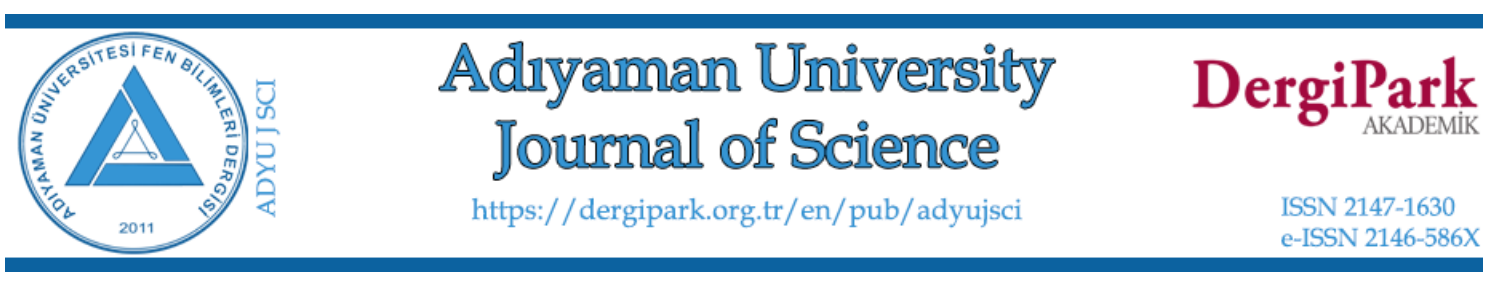

\title{
Inhibition of Colorectal Cancer Cell Survival by Paclitaxel Combined with
}

Olaparib

\author{
Ramazan GÜNDOĞDU ${ }^{1, *}$

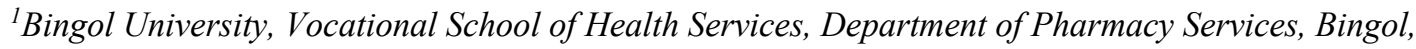 \\ Turkey \\ rgundogdu@bingol.edu.tr,ORCID: 0000-0001-5230-2121
}

\begin{tabular}{lll}
\hline Received: 14.05 .2020 & Accepted: 22.10.2020 & Published: 30.12 .2020
\end{tabular}

\begin{abstract}
Colorectal cancer is one of the main reasons for cancer-related mortality around the world and conventional chemotherapy approaches lead the clinical management of colorectal cancer treatment. Although many chemotherapeutics including paclitaxel have been effectively used to treat colorectal cancer patients, some tumour cells acquire drug resistance by increasing the regulation of various cellular mechanisms, primarily becoming addictive to some DNA repair activities. Preclinical evaluation of small-molecule inhibitors targeting various DNA damage response components is currently an active area of cancer research. This study aimed to assess the cytotoxic effect of paclitaxel combined with small-molecule PARP inhibitor olaparib in HCT116 colorectal cancer cells. We conducted clonogenic assays, showing that the paclitaxel and olaparib combination significantly inhibits the survival of colorectal cancer cells compared to paclitaxel or olaparib alone. By performing two distinct immunological methodology, Western blotting and immunofluorescence, we further demonstrated that olaparib intensifies the DNA damage accumulation induced by paclitaxel treatment. In conclusion, our preclinical study with HCT116 colorectal cancer cells suggests that olaparib may potentially serve as a combination partner to paclitaxel for effective colorectal cancer treatment.
\end{abstract}

Keywords: Colorectal cancer; Paclitaxel treatment; PARP inhibitors. 


\section{HCT116 Kolorektal Kanser Hücre Sağ-kalımının Paklitaksel ve Olaparib Kombinasyon Tedavisiyle Engellenmesi}

\section{$\ddot{O} z$}

Kolorektal kanser, dünya genelinde kansere bağlı ölümün temel sebeplerinden biridir ve konvansiyonel kemoterapi yaklaşımları kolorektal kanser tedavisinin klinik yönetimine öncülük etmektedir. Paklitaksel dahil olmak üzere çoğu kemoterapötik, kolorektal kanser hastalarını tedavi etmede etkili bir şekilde kullanılmasına rağmen, bazı tümör hücreleri özellikle çeşitli DNA tamir aktivitelerine bağımlılık kazanmak suretiyle çok sayıda hücresel mekanizmaların düzenlenmesini arttırarak ilaç direnci kazanırlar. Çeşitli DNA hasar yanıtı bileşenlerini hedefleyen küçük-moleküllü inhibitörlerin klinik öncesi değerlendirmesi günümüzde kanser araştırmalarının aktif bir alanını oluşturmaktadır. Bu çalışma, HCT116 kolorektal kanser hücrelerinde paklitaksel ile kombine edilen küçük-moleküllü PARP inhibitörü olaparibin sitotoksik etkisini değerlendirmeyi amaçlamıştır. Gerçekleştirdiğimiz koloni sağ-kalım analizleri paklitaksel ve olaparib kombinasyonunun sadece paklitaksel ya da olaparib tedavisi ile kıyas edildiğinde kolorektal kanser hücrelerinin sağ kalımını önemli derecede inhibe ettiğini gösterdi. Western blot ve immünofloresan olmak üzere iki farklı immünolojik yöntem gerçekleştirilerek, olaparibin paklitaksel tedavisinin oluşturduğu DNA hasarı birikimini yoğunlaştırdığı tespit edildi. Sonuç olarak, HCT116 kolorektal kanser hücreleriyle gerçekleştirdiğimiz klinik öncesi çalışmamız, olaparib ve paklitaksel kombinasyonunun kolorektal kanser tedavisi için potansiyel bir tedavi yaklaşımı sunabileceğini göstermektedir.

Anahtar Kelimeler: Kolorektal kanser; Paklitaksel tedavisi; PARP inhibitörleri.

\section{Introduction}

Colorectal cancer is the third common type of malignancy worldwide, leading one of the major causes of cancer-related mortality [1]. Surgery is offered for colorectal cancer patients as the most effective treatment option and chemotherapeutical agents are mainly used to eliminate the remaining cancerous cells, repressing tumour growth and reducing recurrence of the disease [2]. Although widely-used anti-cancer agents have improved the prognosis of colorectal cancer in the clinic, their lack of selectivity and acquired resistance remain as one of the major obstacles of the treatment management [3]. Therefore, it is necessary to offer novel treatment strategies that eradicate cancer cells by targeting different cellular mechanisms at the same time.

Paclitaxel has been used as an anti-cancer agent in the treatment of various malignancies. It binds to tubulin and stabilizes polymerized microtubules, arresting cell cycle at the $\mathrm{G} 2 / \mathrm{M}$ 
checkpoint and consequently leading apoptotic cell death [4-6]. The single-agent treatment of high-dose paclitaxel is limited due to difficult-to-tolerate side effects such as peripheral neuropathy and hypersensitivity [7] and acquired paclitaxel resistance through numerous mechanisms including microtubule mutations prevents the long-term clinical success [8]. Considering these drawbacks of high-dose paclitaxel therapy, recent studies have revealed that low-dose paclitaxel application may promise better treatment approach for some malignancies owing to more tolerable toxicity and considerable reduction in drug resistance [9-13]. The cytotoxic effect of paclitaxel treatment was also evaluated in colorectal cancer cells $[14,15]$. Li et al. reported that the low-dose paclitaxel treatment inhibits cell cycle at G0/G1 phase in HCT116 and LOVO cells by modulating the expression of Myc and phosphorylated-c-Myc [15]. Theoretically, low-dose paclitaxel treatment is utilized to suppress the invasive progress and metastatic activities of cancer instead of eliminating neoplastic cells through apoptotic cell death as in the conventional approach. However, contrary research argues that long-term low-dose paclitaxel single-agent therapy may provoke adverse effects such as promoting metastasis [16]. Therefore, researchers have been studying to evaluate the potential of paclitaxel at a low toxic dose combined with small-molecule inhibitors in different experimental settings [17]. Taken together, a combination of paclitaxel and novel small-molecule inhibitors may potentially offer more effective and tolerable anti-cancer responses for the treatment of colorectal cancer patients.

DNA is subjected continual insults from endogenous and exogenous sources and key proteins involved in DNA damage response (DDR) pathway are required to monitor the integrity of genetic material and to activate cell cycle checkpoints once the damage induced, including poly ADP-ribose (PAR) polymerases (PARP) [18, 19]. The PARP enzymes are classified under the group of ADP-ribosyltransferases (ARTs) and contribute to a variety of essential cellular processes including chromatin modification, cell cycle checkpoint regulation and the repair of DNA single-strand breaks (SSBs) [20, 21]. The enzymatic activity of PARPs can be silenced by PARP inhibitors, some of those have been subjected to intense preclinical and clinical investigations for the treatment of certain cancer patients with $B R C A 1 / 2$ mutations either alone or in combination with chemotherapy drugs [22]. PARP inhibitors olaparib, rucaparib and niraparib have been granted the USFDA approval for the treatment of patients with germline $B R C A$-mutant ovarian cancer [23]. Olaparib has recently been approved for germline $B R C A$-mutant metastatic breast [24] and pancreatic cancer treatments [25]. The effective use of PARP inhibitors in the management of colorectal cancer treatment has recently gained attention. Arena et al. demonstrated that PARP inhibitors have a potential to limit colorectal tumour growth and disease progression [26]. It has been also revealed that colorectal cancer cells become vulnerable to irinotecan therapy upon treatment of PARP inhibitors rucaparib [27] or niraparib [28]. Here, we 
hypothesized that the combination treatment of microtubule-targeting agent paclitaxel and PARP inhibitor olaparib would synergize the cytotoxic activities of these molecules, potentially offering more solid management of colorectal cancer treatment. We found that olaparib may intensify paclitaxel cytotoxicity through increasing the overall DNA damage burden in HCT116 colorectal cancer cells.

\section{Materials and Methods}

\subsection{Reagents}

Dulbecco's modified Eagle's medium (DMEM) and fetal bovine serum (FBS) were purchased from Gibco (Thermo Fisher Scientific). Penicillin and streptomycin were purchased from Sigma Aldrich and Bioshop Canada, respectively. Dimethyl sulfoxide (DMSO) and crystal violet were purchased from Bioshop Canada and Sigma Aldrich, respectively. The primary antibodies for anti- $\gamma \mathrm{H} 2 \mathrm{AX}$ (Ser139) and $\beta$-Actin were bought from Cell Signaling Technology (\#9718) and Santa Cruz (\#sc-1616), respectively. The HRP-linked secondary antibodies against anti-rabbit and anti-goat were purchased from GE Healthcare (\#GENA934) and Santa Cruz (\#sc2056). The fluorescent-dye conjugated secondary antibody against anti-rabbit was bought from Stratech - Jackson (Texas Red, \#711-075-152) and DAPI was from Sigma Aldrich (\#32670). Olaparib, rucaparib and paclitaxel were purchased from Selleckchem (\#S1060), Tocris (\#6230) and Medchem Express (\#HY-B0015), respectively.

\subsection{Cell culture conditions}

HCT116 colorectal cancer cell line was kindly provided by Dr Alexander Hergovich (UCL, London, UK) and maintained in high glucose DMEM supplemented with $10 \%$ fetal bovine serum with $1 \%$ antibiotic (pen-strep). Cells were grown in humidity-saturated cell culture incubators at $37^{\circ} \mathrm{C}$ with $5 \% \mathrm{CO}$. Stock solutions of olaparib, rucaparib and paclitaxel were prepared in DMSO and stored at $-80^{\circ} \mathrm{C}$. Drug/inhibitor treatments were performed as indicated in the corresponding figure legends.

\subsection{Clonogenic survival assays}

Clonogenic survival assays were performed as described in [29]. Briefly, 1500 of exponential phase cells were seeded in 6-cm plates and allowed to adhere for 24 hours, before being treated with olaparib or rucaparib with/out paclitaxel for 3 days. Cell medium was refreshed every 4 days until each colony has more than 50 cells (8-10 days). Colonies were first fixed with methanol/acidic acid (3:1) solution, then stained with $0.5 \%$ crystal violet dissolved in methanol 
for 15 minutes. After letting the plates air-dry overnight at room temperature, the number of colonies was counted per plate. The plating efficiencies of the corresponding controls were used to calculate the surviving fraction.

\subsection{Western blotting}

Protein lysates were resolved by $12 \%$ sodium dodecyl sulfate-polyacrylamide gel electrophoresis (SDS-PAGE). Samples were transferred to polyvinylidene difluoride (PVDF) membranes. Membranes were blocked with 5\% skim milk prepared in TBS-T (50 mM Tris, 150 $\mathrm{mM} \mathrm{NaCl}, 0.5 \%$ Tween-20, $\mathrm{pH}$ 7.5) and then incubated with the corresponding antibody overnight. The protein-antibody complex was then probed by secondary antibodies conjugated with horseradish peroxidase (HRP) and finally subjected to ECL (Amersham) substrates for chemiluminescent detection. Densitometry analysis of Western blots was conducted using the NIH ImageJ.

\subsection{Immunofluorescence microscopy}

Immunofluorescence experiments were conducted as defined in [30]. Briefly, cells cultured on glass coverslips were fixed in 3\%-paraformaldehyde (PFA) and 2\%-sucrose solution for 20 minutes at room temperature, permeabilized for 2 minutes with $0.5 \%$ (vol/vol) Triton X-100 in PBS, washed in PBS, and then incubated with anti- $\gamma \mathrm{H} 2 \mathrm{AX}$ primary antibody $(1: 100)$ overnight at $4^{\circ} \mathrm{C}$. Following the washing step, the coverslips were incubated with blocking buffer $(10 \%$ goat serum) before being incubated with anti-rabbit Texas Red secondary antibody (1:100) and DAPI $(1 \mu \mathrm{g} / \mathrm{mL})$ for 2 hours in the dark at room temperature, washed with PBS, and mounted using Vectashield mounting medium (Vector Lab) in a microscope slide. Finally, the corners of the cover slides were sealed with nail polish and images were obtained with an Apotome fluorescence microscope (Zeiss) and Photoshop CS5 (Adobe Systems Inc.).

\subsection{Statistical analysis}

GraphPad Prism software was used to acquire graphics and statistical analyses. Data are displayed as mean \pm SEM. The significance of differences between the means was one-tailed unpaired Student's t-test for colony survival assays and Mann-Whitney test for immunofluorescence analyses. Differences were considered statistically significant when $p$ values were below $0.05(*), 0.01(* *), 0.001(* * *)$ or $0.0001(* * * *)$ for all experiments. 


\section{Results}

\subsection{Paclitaxel and Olaparib Combination Inhibits HCT116 Cancer Cell Survival}

As a widely used anti-neoplastic agent in the clinic [5], paclitaxel treatment causes tubulin polymerization, dysfunctional microtubule formation and cell cycle arrest, ultimately inducing cell death $[4,6,31]$. Here, the cytotoxic effect of paclitaxel alone or in combination with smallmolecule PARP inhibitors olaparib and rucaparib (Fig. 1A) were examined by in vitro clonogenic analysis. We employed HCT116 colorectal cancer cells characterized by microsatellite instability (MSI) [32], displaying inefficient mismatch repair and chemoresistant profile [33]. First, the cytotoxic capacity of paclitaxel single-agent treatment was evaluated in HCT116 cells. After being treated with various doses of paclitaxel $(1-10 \mathrm{nM})$ for 3 days, cells were further cultured in the drug-free medium for another 8 to 10 days in order to assess the paclitaxel cytotoxicity. Our results demonstrated that the paclitaxel treatment of $1 \mathrm{nM}$ had a minimal cytotoxic effect on the HCT116 cell survival compared to higher doses and this result prompted us to select $1 \mathrm{nM}$ paclitaxel concentration as a low-dose treatment for future combination experiments. In addition, based on our preliminary studies and the literature [34,35], we used 0.5 and $1 \mu \mathrm{M}$ olaparib, and 0.1 and $0.5 \mu \mathrm{M}$ rucaparib preclinical doses in our paclitaxel combination experiments with HCT116 cells.

A

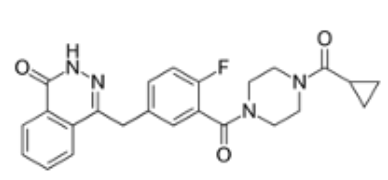

olaparib

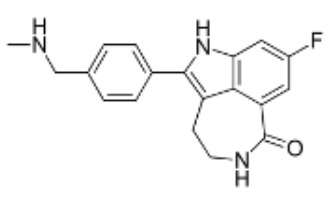

rucaparib

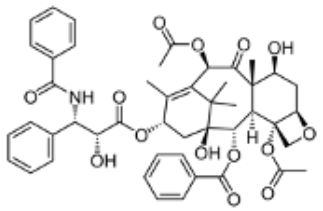

paclitaxel
B

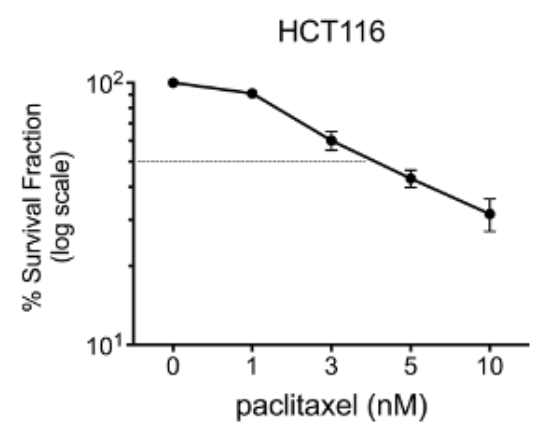

C

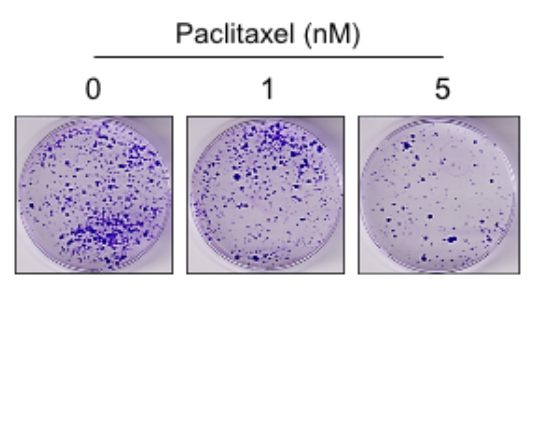

Figure 1: Cytotoxic effect of paclitaxel treatment on HCT116 colorectal cancer cells. (A) The chemical structure of olaparib, rucaparib and paclitaxel, (B) clonogenic survival of HCT116 cells treated with/out paclitaxel for 3 days. Quantifications are shown as a percentage (in log scale) of colonies formed after treatment with indicated doses $(n=3)$. Results were corrected according to plating efficiencies of the corresponding untreated controls, (C) representative images of the clonogenic survival assays 
Next, we evaluated the combined effect of paclitaxel $(1 \mathrm{nM})$ and olaparib treatment on the clonogenic capacity of HCT116 cells. Cells were treated with olaparib $(0.5$ and $1 \mu \mathrm{M})$ alone or in combination with paclitaxel $(1 \mathrm{nM})$ for 3 days, then further incubated with the medium without any drug. Interestingly, the paclitaxel and olaparib combination treatment had significantly repressed the survival of HCT116 colorectal cancer cells compared to the relevant single-agent treatments (Fig. 2A/B). This synergistic cytotoxicity was specific to HCT116 colorectal cancer cells since the combination treatment did not affect the clonogenic survival of U2OS osteosarcoma cells that were subjected to the same experimental procedures (Fig. 2C).

A HCT116

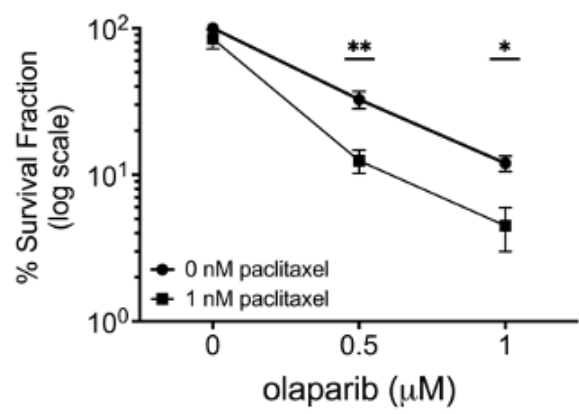

B

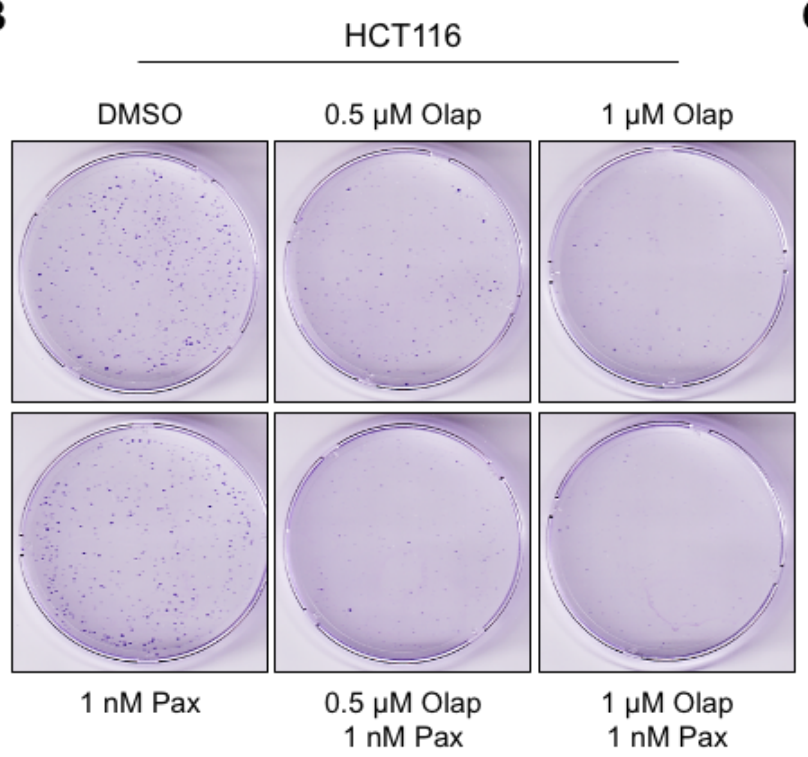

C
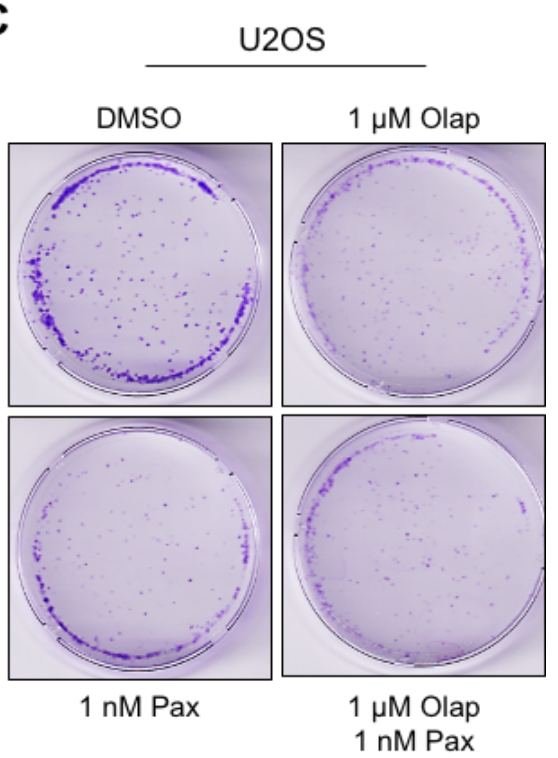

Figure 2: Olaparib enhances the cytotoxicity of paclitaxel in HCT116 cells. (A) Clonogenic survival of HCT116 cells in response to paclitaxel treatment $(1 \mathrm{nM})$ with/out olaparib $(0.5$ and $1 \mu \mathrm{M})$ for 3 days. Quantifications are shown as a percentage (in log scale) of colonies formed after treatment with indicated doses $(n=3)$. Results were corrected according to plating efficiencies of the corresponding untreated controls, (B) representative images of the clonogenic survival assays, (C) representative images of the U2OS clonogenic survival upon paclitaxel alone or in combination with olaparib for 3 days

To consolidate our findings, we further analyzed the cytotoxic activity of paclitaxel combined with rucaparib, another USFDA approved small-molecule PARP inhibitor, in HCT116 
cancer cells. Cells were treated with rucaparib $(0.1$ and $0.5 \mu \mathrm{M})$ alone or in combination with paclitaxel $(1 \mathrm{nM})$ for 3 days as detailed above. In line with previous results, we noticed a significant reduction in colony survival of HCT116 cells upon paclitaxel and rucaparib combination regimen compared to the relevant single-agent treatments (Fig. 3A/B). In summary, our clonogenic survival experiments revealed that HCT116 colorectal cancer cells become vulnerable to PARP inhibitor treatment when paclitaxel is included as a combination partner.

A

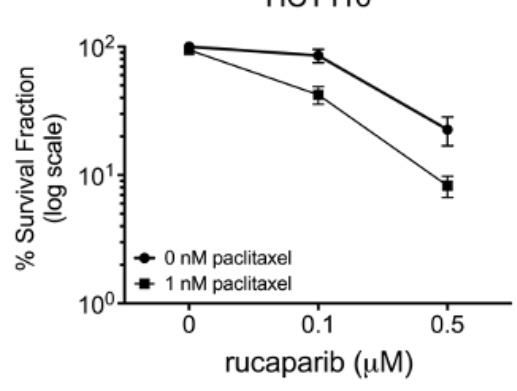

B

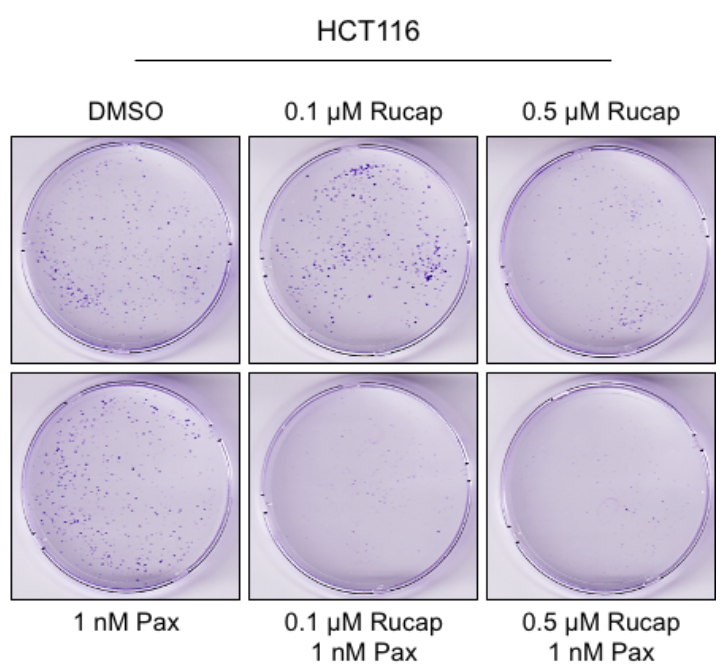

Figure 3: Rucaparib potentiates paclitaxel cytotoxicity in HCT116 cells. (A) Clonogenic survival of HCT116 cells in response to paclitaxel treatment $(1 \mathrm{nM})$ with/out rucaparib $(0.1$ and $0.5 \mu \mathrm{M})$ for 3 days. Quantifications are shown as a percentage (in log scale) of colonies formed after treatment with indicated doses $(n=2)$. Results were corrected according to plating efficiencies of the corresponding untreated controls, (B) representative images of the clonogenic survival assays

\subsection{Olaparib treatment augments the Paclitaxel-induced DNA damage accumulation}

\section{in $\mathrm{HCT} 116$ cells}

After deciphering that HCT116 colorectal cancer cells have significantly impaired clonogenic capacity upon the paclitaxel and olaparib combination treatment, we further investigated the level of DNA damage induction in HCT116 cancer cell treated with paclitaxel and olaparib combined or alone. As a reliable DNA damage indicator [36], the phosphorylation status of $\mathrm{H} 2 \mathrm{AX}(\gamma \mathrm{H} 2 \mathrm{AX}-\mathrm{Ser} 139)$ was assessed by conducting Western blotting. HCT116 cells were treated with olaparib $(1 \mu \mathrm{M})$ or paclitaxel $(1 \mathrm{nM})$ as single agents or in combination for 24 hours. Following treatment, cells were incubated with the drug-free medium for additional 4 hours for the recovery before being subjected to Western blotting analysis (Fig. 4A). As presented in Fig. $4 \mathrm{~B} / \mathrm{C}$, both olaparib and paclitaxel single-agent treatments increased the $\gamma \mathrm{H} 2 \mathrm{AX}$ levels (lines 3 and 4); however, the combination treatment of paclitaxel and olaparib resulted in higher and 
sustained $\gamma \mathrm{H} 2 \mathrm{AX}$ induction (line 5), suggesting an insistent DNA damage accumulation in HCT116 colorectal cancer cells upon the combined treatment.

A

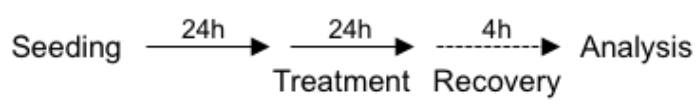

B

HCT116

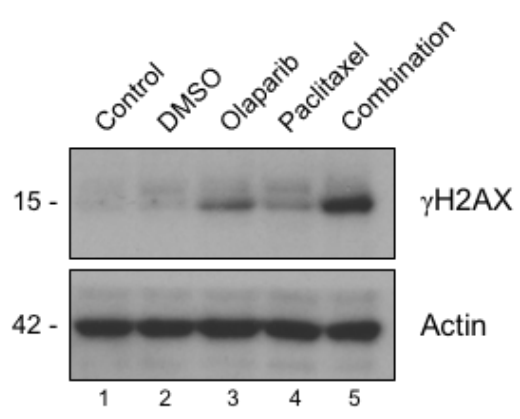

C

HCT116

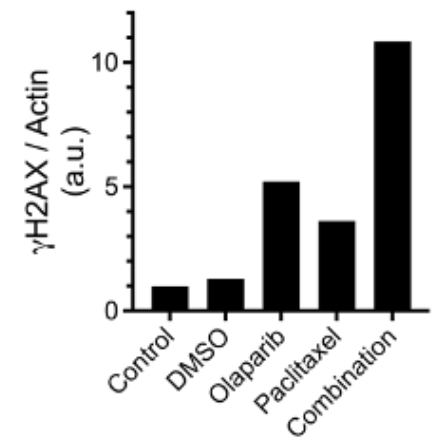

Figure 4: The olaparib-paclitaxel combination induces intensive DNA damage. (A) Schematic diagram of the experimental setting, (B) Phosphorylation of H2AX was analyzed by Western blotting. Following 24 hours of seeding, HCT116 cells were either un-treated (control) or treated with DMSO, olaparib $(1 \mu \mathrm{M})$ and/or paclitaxel $(1 \mathrm{nM})$ for 24 hours. Following treatment, cells were allowed to recover in drug-free medium for 4 hours and then processed for Western blotting, (C) histogram showing H2AX activation as judged by Ser139 phosphorylation obtained by densitometric quantification of Western blots represented in B. Arbitrary units were normalized to the expression of the corresponding $\beta$-actin

To further investigate whether the improved cytotoxic effect of the paclitaxel-olaparib combination was the consequence of increased DNA damage levels, we examined DNA damage induction by analyzing $\gamma \mathrm{H} 2 \mathrm{AX}$ foci formation. Cells seeded in the glass coverslips were treated with paclitaxel $(1 \mathrm{nM})$ and olaparib $(1 \mu \mathrm{M})$ alone or in combination for 24 hours before being subjected to the immunofluorescence analysis. Consistent with Western blotting analysis, we observed a significant elevation of $\gamma \mathrm{H} 2 \mathrm{AX}$ foci formation in HCT116 cancer cells treated with paclitaxel and rucaparib combination compared to monotherapy of each drug (Fig. 5A/B), suggesting that olaparib may intensify the cytotoxicity effect of paclitaxel through increasing the overall DNA damage accumulation in HCT116 colorectal cancer cells. Consequently, the increased DNA damage burden upon the combination treatment of paclitaxel and olaparib is the most likely cause of the reduced colony survival of HCT116 cancer cells. 
A

HCT116

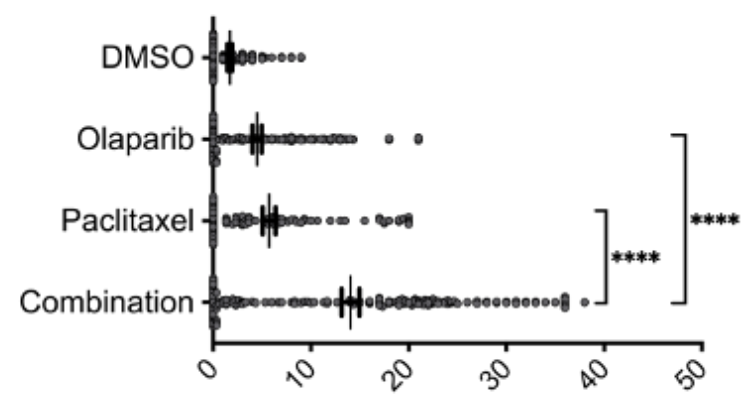

$\gamma \mathrm{H} 2 \mathrm{AX}$ foci counts per nucleus

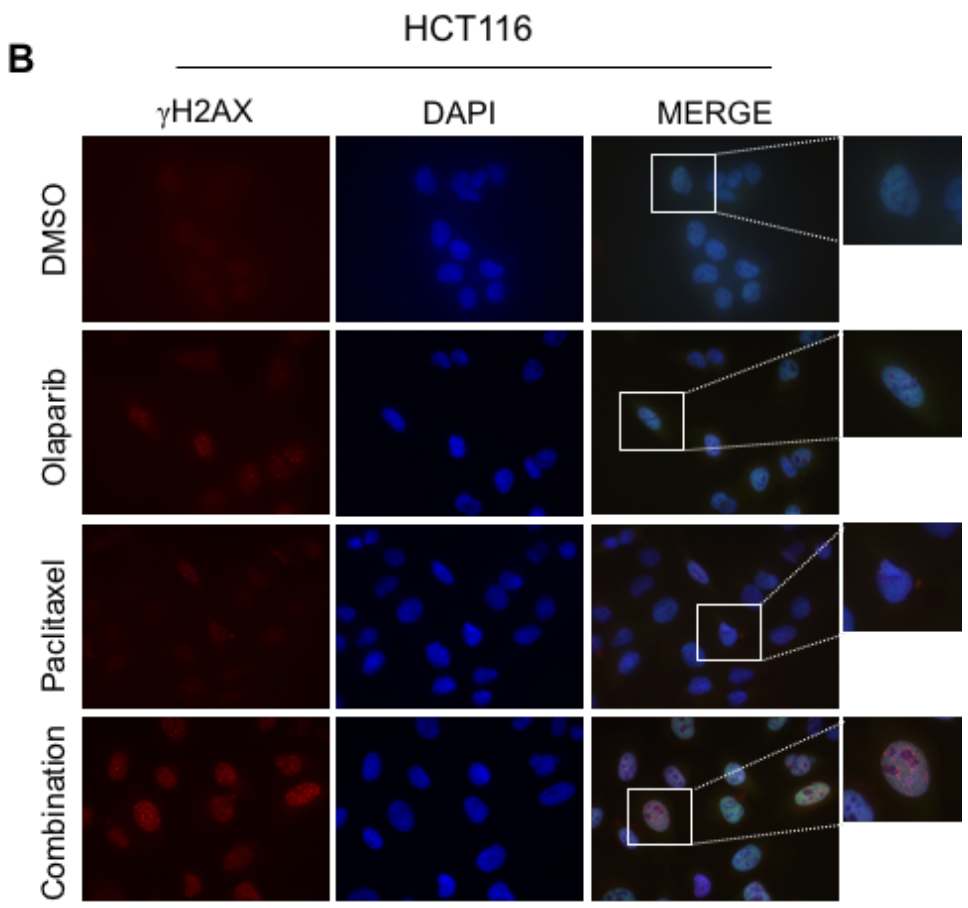

Figure 5: Paclitaxel-induced DNA damage is intensified upon olaparib treatment. (A) The dot blot graph represents quantification of nuclear $\gamma \mathrm{H} 2 \mathrm{AX}$ foci number in HCT116 cells treated with/out olaparib $(1 \mu \mathrm{M})$ and/or paclitaxel $(1 \mathrm{nM})$. $>100$ cells were scored per experiment $(\mathrm{n}=3)$, (B) representative images of immunodetection of $\gamma \mathrm{H} 2 \mathrm{AX}$ foci (red) in HCT116 cells exposed to beforementioned treatments for 24 hours. DNA is stained blue

\section{Discussion}

Cytotoxic chemotherapy is widely used for the management of many cancer treatments; however, de novo or acquired drug resistance, as well as side effects, limit the clinical success of anti-neoplastic agents. The main mechanism of action of the most chemotherapeutics is to bombard the genome with various types of DNA lesions up to a certain level that a cell decides to death [37]. This intensified DNA damaging pressure increases the genomic instability of 
tumour cells, provoking them to alter the regulation of various cellular pathways to survive including DNA damage response (DDR) and repair mechanisms. Therefore, the combination of conventional drugs with smart small-molecule inhibitors targeting DDR components would potentially offer better treatment responses. Unlike directly DNA damaging cytotoxic drugs, paclitaxel interferes with the disassembly of microtubules by promoting tubulin polymerization. The formation of stable and dysfunctional microtubules causes the inhibition of cell cycle regulation and ultimately induces cell death [4-6,31]. In this study, the combination of low-dose paclitaxel with olaparib or rucaparib was evaluated for treating colorectal cancers. The combination treatment of HCT116 cells with paclitaxel and olaparib revealed a much stronger inhibitory effect on clonogenic formation compared with paclitaxel or olaparib alone. Rucaparib treatment with paclitaxel provided similar results in the clonogenic evaluation of HCT116 cells. It has been shown that $1 \mathrm{nM}$ paclitaxel treatment arrests the cell cycle at the G1 phase in HCT116 cells [12]. Considering PARP enzymes essential for the induction of G1 arrest [38], one can argue that PARP inhibition may potentially prevent the G1 arrest and therefore allow paclitaxel-treated cancer cells with dysfunctional microtubules towards the $\mathrm{S}$ phase, consequently causing more catastrophic DNA damage induction. Indeed, we revealed that HCT116 colorectal cancer cells acquired more DNA damage upon the combined paclitaxel and olaparib treatment compared to single-agent treatments. HCT116 colorectal cancer cells are deficient in mismatch repair and therefore characterized by microsatellite instability (MSI) [32]. Williams et al. demonstrated that the MSI status of colorectal cancer cells is dispensable for the response to PARP inhibitor niraparib, alone or in combination with DNA damaging agent irinotecan [28]. Therefore, further research is warranted to fully understand whether the genomic and proteomic profiles of HCT116 cells [32] are significant in this enhanced therapeutic response to paclitaxel and olaparib combined treatment. In addition, since paclitaxel can also cause DNA single-strand breaks (SSBs) [39-41], deficient SSB repair due to PARP inhibition may induce the accumulation of paclitaxel-induced SSBs which are eventually converted to disastrous DNA double-strand breaks (DSBs) during DNA replication [42]. Inefficient homologous recombination DSB repair mechanism owing to a possible BRCA2 mutation in HCT116 cells [32] may also explain why the paclitaxel-olaparib treatment induces more DNA damage and less clonogenic survival of HCT116 cells. Detailed mechanisms remain to be elucidated.

\section{Conclusion}

The efficacy of paclitaxel and olaparib, both alone and in combination, was assessed in HCT116 colorectal cancer cells. Our results suggest that the combination of paclitaxel and 
olaparib may need to be further studied to enhance the therapeutic responses of colorectal cancer patients.

\section{Acknowledgement}

The author thanks Dr. M.K. Erdogan and S. Acikgoz for critical reading of the manuscript. The author further acknowledges the funding supports of the Scientific and Technological Research Council of Turkey (TUBITAK 119S007) and the Scientific Research Projects Coordination Unit of Bingol University (BAP-SHMYO.2019.00.002).

\section{References}

[1] Bray, F., Ferlay, J., Soerjomataram, I., Siegel, R.L., Torre, L.A., Jemal, A., Global cancer statistics 2018: GLOBOCAN estimates of incidence and mortality worldwide for 36 cancers in 185 countries, CA: A Cancer Journal for Clinicians, 68(6), 394-424, 2018.

[2] Ades, S., Adjuvant chemotherapy for colon cancer in the elderly: Moving from evidence to practice, Oncology, 23(2), 162-167, 2009.

[3] Jensen, N.F., et al., Establishment and characterization of models of chemotherapy resistance in colorectal cancer: Towards a predictive signature of chemoresistance, Molecular Oncology, 9(6), 1169-1185, 2015.

[4] Othman, T., Goto, S., Lee, J.B., Taimura, A., Matsumoto, T., Kosaka, M., Hyperthermic enhancement of the apoptotic and antiproliferative activities of paclitaxel, Pharmacology, 62(4), 208-212, 2001.

[5] Barbuti, A.M., Chen, Z.S., Paclitaxel through the ages of anticancer therapy: Exploring its role in chemoresistance and radiation therapy, Cancers, 7(4), 2360-2371, 2015.

[6] Rowinsky, E.K., Donehower, R.C., Paclitaxel (Taxol), New England Journal of Medicine, 332(15), 1004-1014, 1995.

[7] Banerji, A., Lax, T., Guyer, A., Hurwitz, S., Camargo, C.A., Long, A.A., Management of hypersensitivity reactions to carboplatin and paclitaxel in an outpatient oncology infusion center: A 5-year review, The Journal of Allergy and Clinical Immunology: In Practice, 2(4), 428433, 2014.

[8] Orr, G.A., Verdier-Pinard, P., McDaid, H., Horwitz, S.B., Mechanisms of Taxol resistance related to microtubules, Oncogene, 22(47), 7280-7295, 2003.

[9] Lien, K., Georgsdottir, S., Sivanathan, L., Chan, K., Emmenegger, U., Low-dose metronomic chemotherapy: A systematic literature analysis, Eurepean Journal of Cancer, 49(16), 3387-3395, 2013.

[10] Loven, D., Hasnis, E., Bertolini, F., Shaked, Y., Low-dose metronomic chemotherapy: From past experience to new paradigms in the treatment of cancer, Drug Discovery Today, 18(34), 193-201, 2013.

[11] Gong, L.H., et al., Piperlongumine induces apoptosis and synergizes with cisplatin or paclitaxel in human ovarian cancer cells, Oxidative Medicine and Cellular Longevity, 906804, 1-10, 2014.

[12] Lv, C., et al., Low-dose paclitaxel inhibits tumor cell growth by regulating glutaminolysis in colorectal carcinoma cells, Frontiers in Pharmacology, 8(244), 1-10, 2017. 
[13] Cheng, M., et al., Weekly dose-dense paclitaxel and triweekly low-dose cisplatin: A well-tolerated and effective chemotherapeutic regimen for first-line treatment of advanced ovarian, fallopian tube, and primary peritoneal cancer, International Journal of Environmental Research and Public Health, 16(23), 4794, 2019.

[14] Kennedy, A.S., Harrison, G. H., Mansfield, C. M., Zhou, X. J., Xu, J. F., BalcerKubiczek, E. K., Survival of colorectal cancer cell lines treated with paclitaxel, radiation, and 5FU: Effect of TP53 or hMLH1 deficiency, International Journal of Cancer, 90(4), 175-185, 2000.

[15] Li, H., et al., Low-dose paclitaxel downregulates MYC proto-oncogene bHLH transcription factor expression in colorectal carcinoma cells, Oncology Letters, 15(2), 18811887, 2018.

[16] Li, Q., et al., Low doses of paclitaxel enhance liver metastasis of breast cancer cells in the mouse model, The FEBS Journal, 283(15), 2836-2852, 2016.

[17] Shetti, D., Zhang, B., Fan, C., Mo, C., Lee, B.H., Wei, K., Low Dose of Paclitaxel Combined with XAV939 Attenuates Metastasis, Angiogenesis and Growth in Breast Cancer by Suppressing Wnt Signaling, Cells, 8(8), 1-22, 2019.

[18] Ciccia, A., Elledge, S.J., The DNA Damage Response: Making It Safe to Play with Knives, Molecular Cell, 40(2), 179-204, 2010.

[19] Goldstein, M., Kastan, M.B., The DNA Damage Response: Implications for Tumor Responses to Radiation and Chemotherapy, Annual Review of Medicine, 66(1), 129-143, 2015.

[20] Sonnenblick, A., de Azambuja, E., Azim, H.A., Piccart, M., An update on PARP inhibitors-moving to the adjuvant setting, Nature Review Clinical Oncology, 12(1), 27-41, 2015.

[21] Morales, J.C., et al., Review of poly (ADP-ribose) polymerase (PARP) mechanisms of action and rationale for targeting in cancer and other diseases, Critical Reviews in Eukaryotic Gene Expression., 24(1), 15-28, 2014.

[22] Dréan, A., Lord, C.J., Ashworth, A., PARP inhibitor combination therapy, Critical Reviews in Oncology/Hematology, 108, 73-85, 2016.

[23] Walsh, C., Targeted therapy for ovarian cancer: The rapidly evolving landscape of PARP inhibitor use, Minerva Ginecologica, 70(2), 150-170, 2018.

[24] The Food and Drug Administration (FDA). (2020, May 01). FDA approves olaparib for germline BRCA-mutated metastatic breast cancer, 2018.

[25] The Food and Drug Administration (FDA). (2020, May 01). FDA approves olaparib for gBRCAm metastatic pancreatic adenocarcinoma, 2019.

[26] Arena, S., et al., A subset of colorectal cancers with cross-sensitivity to olaparib and oxaliplatin, Clinical Cancer Research, 26(6), 1372-1384, 2020.

[27] Augustine, T., Maitra, R., Zhang, J., Nayak, J., Goel, S., Sensitization of colorectal cancer to irinotecan therapy by PARP inhibitor rucaparib, Investigational New Drugs, 37(5), 948-960, 2019.

[28] Genther Williams S.M., et al., Treatment with the PARP inhibitor, niraparib, sensitizes colorectal cancer cell lines to irinotecan regardless of MSI/MSS status, Cancer Cell International., 15(1), 1-11, 2015.

[29] Gomez, V., et al., Regulation of DNA damage responses and cell cycle progression by hMOB2, Cellular Signalling., 27(2), 326-39, 2015.

[30] Hergovich, A., Bichsel, S.J., Hemmings, B.A., Human NDR kinases are rapidly activated by $M O B$ proteins through recruitment to the plasma membrane and phosphorylation, Molecular and Cellular Biology, 25(18), 8259-8272, 2005. 
[31] Weaver, B.A., How Taxol/paclitaxel kills cancer cells, Molecular Biology of the Cell, 25(18), 2677-2681, 2014.

[32] Berg, K.C.G., et al., Multi-omics of 34 colorectal cancer cell lines - a resource for biomedical studies, Molecular Cancer, 16(116), 1-16, 2017.

[33] Duldulao, M.P., et al., Gene expression variations in microsatellite stable and unstable colon cancer cells, Journal of Surgical Research, 174(1), 1-6, 2012.

[34] Shen, J., et al., ARIDIA Deficiency Impairs the DNA Damage Checkpoint and Sensitizes Cells to PARP Inhibitors, Cancer Discovery, 5(7), 752-767, 2015.

[35] Wang, C., Jette, N., Moussienko, D., Gwyn Bebb, D., Lees-Miller, S.P., ATMDeficient Colorectal Cancer Cells Are Sensitive to the PARP Inhibitor Olaparib, Translational. Oncology, 10(2), 190-196, 2017.

[36] Kuo, L.J., Yang, L.X., $\gamma$-H2AX-A novel biomaker for DNA double-strand breaks, In Vivo, 22(3), 305-309, 2008.

[37] Desai, A., Yan, Y., Gerson, S.L., Advances in therapeutic targeting of the DNA damage response in cancer, DNA Repair, 66(67), 24-29, 2018.

[38] Masutani, M., Nozaki, T., Wakabayashi, K., Sugimura, T., Role of poly(ADP-ribose) polymerase in cell-cycle checkpoint mechanisms following $\gamma$-irradiation, Biochimie, 77(6), 462$465,1995$.

[39] Ollikainen, T., et al., In vitro sensitivity of normal human mesothelial and malignant mesothelioma cell lines to four new chemotherapeutic agents, Anticancer Drugs, 11(2), 93-99, 2000.

[40] Digue, L., et al., Evaluation of the genotoxic activity of paclitaxel by the in vitro micronucleus test in combination with fluorescent in situ hybridization of a DNA centromeric probe and the alkaline single cell gel electrophoresis technique (comet assay) in human T-lymph, Environmental and Molecular Mutagen, 34(4), 269-278, 1999.

[41] Branham, M.T., Nadin, S.B., Vargas-Roig, L.M., Ciocca, D.R., DNA damage induced by paclitaxel and DNA repair capability of peripheral blood lymphocytes as evaluated by the alkaline comet assay, Mutation Research/Genetic Toxicology and Environmental Mutagenesis, 560(1), 11-17, 2004.

[42] Bryant, H.E., Helleday, T., Inhibition of poly (ADP-ribose) polymerase activates ATM which is required for subsequent homologous recombination repair, Nucleic Acids Research, 34(6), 1685-1691, 2006. 